\title{
Treatment of a Textile Effluent by Electrochemical Oxidation and Coupled System Electooxidation-Salix babylonica
}

\author{
Alejandra Sánchez-Sánchez, ${ }^{1}$ Moisés Tejocote-Pérez, ${ }^{2}$ Rosa María Fuentes-Rivas, ${ }^{3}$ \\ Ivonne Linares-Hernández, ${ }^{1}$ Verónica Martínez-Miranda, ${ }^{1}$ \\ and Reyna María Guadalupe Fonseca-Montes de Oca ${ }^{1}{ }^{1}$ \\ ${ }^{1}$ Centro Interamericano de Recursos del Agua, Universidad Autónoma del Estado de México, Carretera Toluca-Atlacomulco, Km 14.5 \\ Unidad San Cayetano, 50200 Toluca, MEX, Mexico \\ ${ }^{2}$ Centro de Investigación en Ciencias Biológicas Aplicadas, Universidad Autónoma del Estado de México, Carretera Toluca- \\ Atlacomulco, Km 14.5 Unidad San Cayetano, 50200 Toluca, MEX, Mexico \\ ${ }^{3}$ Facultad de Geografía, Universidad Autónoma del Estado de México, Cerro de Coatepec s/n, Ciudad Universitaria, 50110 Toluca, \\ MEX, Mexico
}

Correspondence should be addressed to Reyna María Guadalupe Fonseca-Montes de Oca; mgfonsecam@uaemex.mx

Received 2 October 2017; Revised 20 March 2018; Accepted 1 April 2018; Published 3 May 2018

Academic Editor: Carlos A Martínez-Huitle

Copyright (c) 2018 Alejandra Sánchez-Sánchez et al. This is an open access article distributed under the Creative Commons Attribution License, which permits unrestricted use, distribution, and reproduction in any medium, provided the original work is properly cited.

\begin{abstract}
The removal of pollutants from textile wastewater via electrochemical oxidation and a coupled system electrooxidation-Salix babylonica, using boron-doped diamond electrodes was evaluated. Under optimal conditions of pH 5.23 and $3.5 \mathrm{~mA} \cdot \mathrm{cm}$ of current density, the electrochemical method yields an effective reduction of chemical oxygen demand by $41.95 \%$, biochemical oxygen demand by $83.33 \%$, color by $60.83 \%$, and turbidity by $26.53 \%$ at 300 minutes of treatment. The raw and treated wastewater was characterized by infrared spectroscopy to confirm the degradation of pollutants. The wastewater was oxidized at 15-minute intervals for one hour and was placed in contact with willow plants for 15 days. The coupled system yielded a reduction of the chemical oxygen demand by $14 \%$, color by $85 \%$, and turbidity by $93 \%$. The best efficiency for the coupled system was achieved at 60 minutes, at which time the plants achieved more biomass and photosynthetic pigments.
\end{abstract}

\section{Introduction}

The textile industry is one of the greatest generators of liquid effluent pollutants due to the high quantities of water used in the dyeing processes. The chemical composition involves a wide range of pollutants: inorganic compounds, polymers, and organic products [1-3]. Treatment of textile dye effluent is difficult and ineffective with conventional processes because many synthetic dyes are very stable in light and high temperature, and they are also nonbiodegradable. Moreover, partial oxidation or reduction can generate very toxic byproducts [4-6].

Advanced oxidation processes (AOPs) have emerged as potentially powerful methods that can transform recalcitrant pollutants into harmless substances. AOPs rely on the generation of very reactive free radicals and very powerful oxidants, such as the hydroxyl radical, $\mathrm{HO} \bullet$ (redox potentia $1=2.8 \mathrm{~V})[7,8]$. These radicals react rapidly with most organic compounds, either by addition to a double bond or by the abstraction of a hydrogen atom from organic molecules $[9,10]$.

The resulting organic radicals, then, react with oxygen to initiate a series of degradative oxidation reactions that lead to products, such as $\mathrm{CO}_{2}$ and $\mathrm{H}_{2} \mathrm{O}[1,11]$. Electrochemical oxidation is carried out by indirect and/or direct anodic reactions in which oxygen is transferred from the solvent (water) to the product to be oxidized [12]. The main characteristic of this treatment is that it uses electrical energy as a vector for environmental decontamination [13]. During direct anodic oxidation, pollutants are initially adsorbed on the 


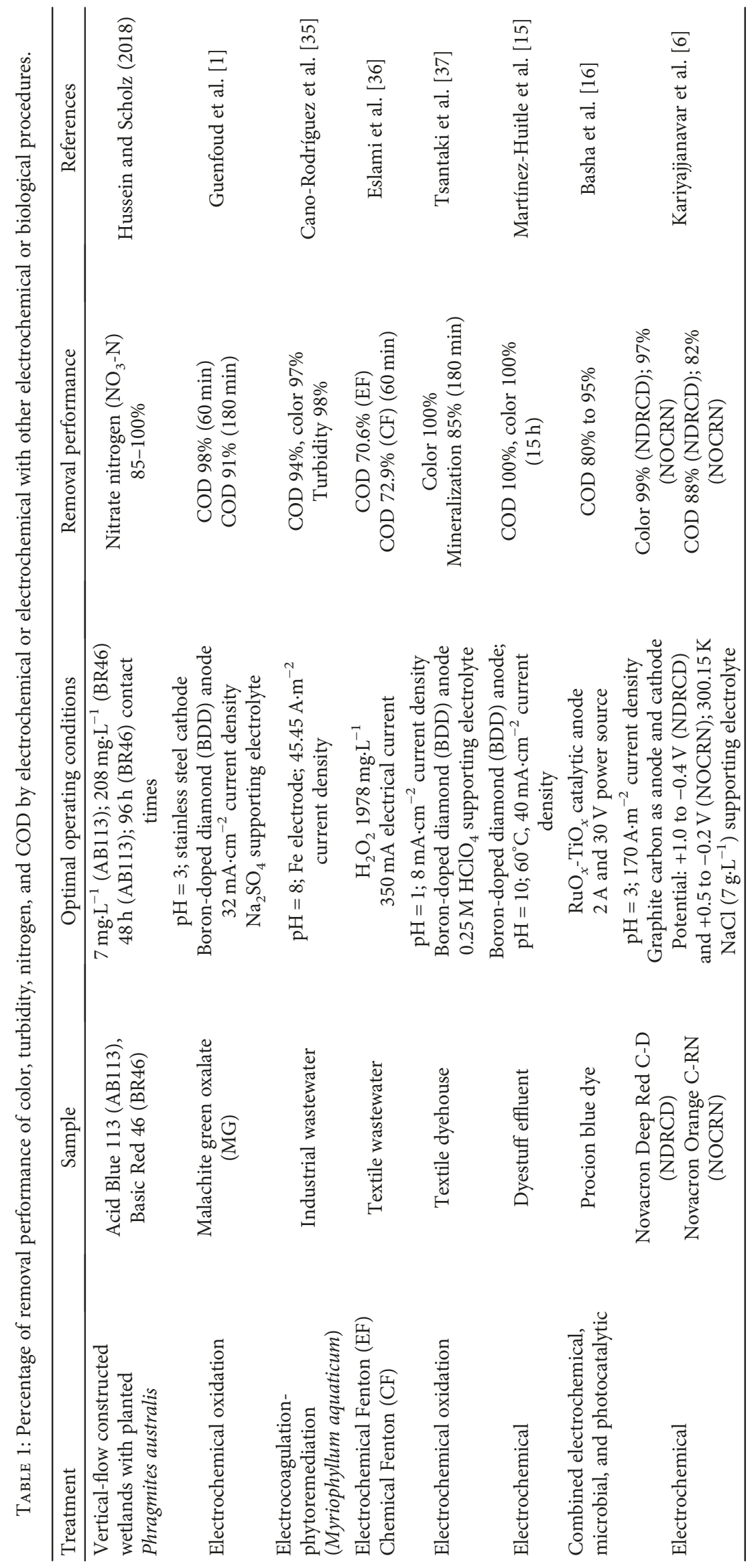




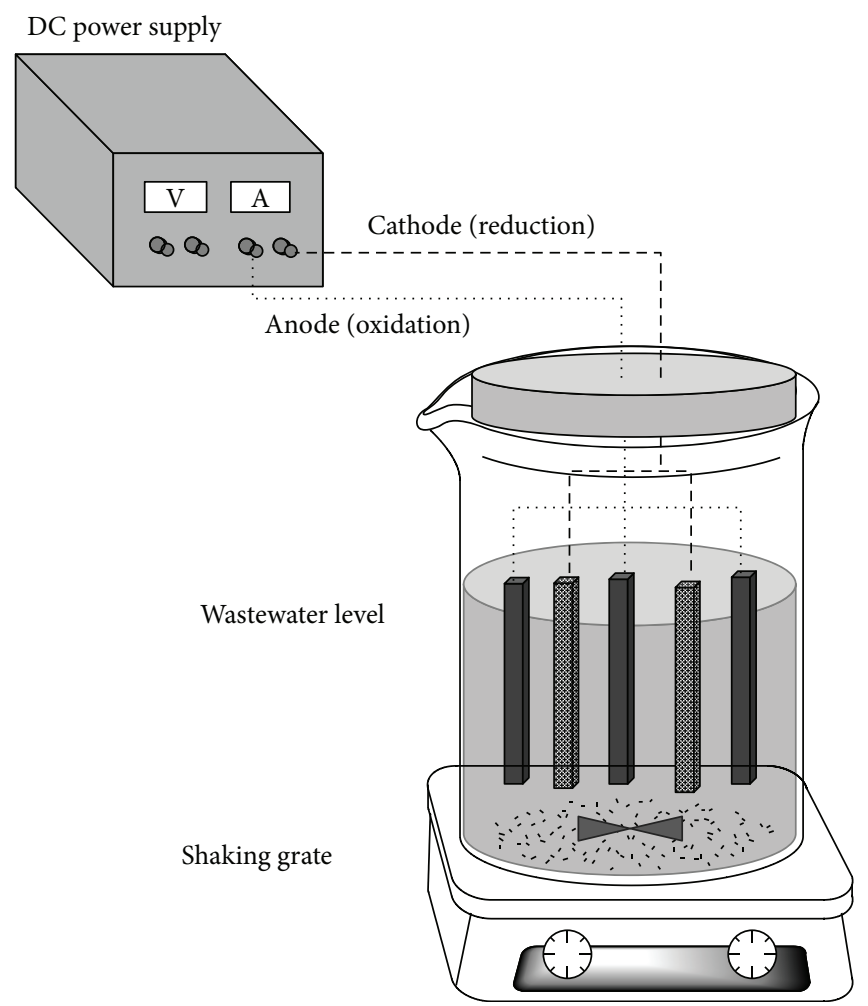

Figure 1: A schematic diagram of the electrochemical reactor.

surface of the anode, where the anodic electron transfer reaction degrades them [6]. In indirect anodic oxidation, strong oxidants, such as hypochlorite, chlorine, ozone, or hydrogen peroxide, are electrochemically generated.

The pollutants are degraded via the oxidation reactions with these strong oxidants [11]. Boron-doped diamond (BDD) thin films are electrode materials that possess several technologically important characteristics, including an inert surface with low adsorption properties, an acceptable conductivity, and remarkable corrosion stability even in strongly acidic media and extremely high $\mathrm{O}_{2}$ evolution overvoltage $[14,15]$.

On the other hand, biotechnology continues to be used to solve environmental problems [16-18]. Phytoremediation (PR) is a green technology that uses plant systems for the remediation and restoration of contaminated sites [19]. PR's advantages are solar energy dependence and an esthetically pleasant method of treatment [20]. Plants have inbuilt enzymatic characteristics that are capable of degrading complex structures, and they can be used for cleaning contaminated sites [17].

Plants, however, remove pollutants predominantly via adsorption, accumulation, and subsequent enzyme-mediated degradation [20]. Therefore, plants are considered organisms with complex metabolic activity when referring to the assimilation of toxic substances. Plant species that have different growth forms have been proposed for the treatment of textile effluents, for instance, Glandularia pulchella, Phragmites australis, Tagetes patula, Alternanthera philoxeroides, Eichhornia crassipes, Nasturtium officinale,
TABle 2: Experimental design of the electrooxidation process.

\begin{tabular}{lcc}
\hline Experiment & $\mathrm{pH}$ & Current density \\
\hline 1 & 5.23 & 3.5 \\
2 & 5.23 & 7 \\
3 & 5.23 & 10 \\
4 & 7 & 3.5 \\
5 & 7 & 7 \\
6 & 7 & 10 \\
7 & 10 & 3.5 \\
8 & 10 & 7 \\
9 & 10 & 10 \\
\hline
\end{tabular}

Hydrocotyle vulgaris, Petunia grandiflora, and Gaillardia grandiflora [17, 18, 21-24].

Another alternative is to use species of fast-growing woody plants with high biomass production and high genetic variability [25-27]. Trees from the Salicaceae family with the genera Salix and Populus are suitable candidates for this purpose [28-30]. Willows (Salix spp.) have several characteristics that make them ideal plant species for PR application, including easy propagation and cultivation, a large amount of biomass, a deep root system, a high transpiration rate, tolerance to hypoxic conditions, and high metal accumulation capability [30, 31].

Salix babylonica has been used to solve the problems associated with aquifers contaminated with ethanol-blended gasoline [32] and studies of the biotransformation and 
metabolic response of cyanide and dieldrin [33, 34]. In recent years, several authors have described dye removal by electrochemical (EC) or coupled electrochemical with other chemical, electrochemical, or biological procedures (Table 1). However, no studies have been conducted on the implementation of coupled electrochemical oxidationphytoremediation with weeping willow in the remediation of textile effluents, and because it is an introduced species, is noninvasive, and is widely distributed in Mexico, the aim of this study was to evaluate the removal of the pollutants of a textile effluent using an electrochemical oxidation process and to compare their performance with Salix babylonica.

\section{Materials and Methods}

2.1. Wastewater Sampling. A textile wastewater sample was collected from a textile industry whose business is the dyeing and washing of denim garments in Almoloya del Río, State of Mexico, Mexico. The wastewater that this industry discharges does not receive any treatment and is discharged into the sewage system, so it is necessary to give it some kind of treatment to improve its quality. The textile wastewater sample was placed in plastic containers and transported to the laboratory, where it was refrigerated at $4^{\circ} \mathrm{C}$ for analysis and for conducting the electrochemical oxidation and coupled system electrooxidation-Salix babylonica.

2.2. Electrochemical Reactor. In this study, a batch electrochemical reactor was used. The reactor contained five vertical parallel electrodes of BDD (titanium/BDD) that CONDIAS DIACHEM manufactured, two as cathodes and three as anodes. Each electrode was $20.5 \mathrm{~cm}$ long and $2.5 \mathrm{~cm}$ wide, resulting in an area of $102.5 \mathrm{~cm}^{2}$ for each electrode and a total anodic area of $307.5 \mathrm{~cm}^{2}$. A schematic diagram of the electrochemical reactor is shown in Figure 1. The tests were carried out in a $1 \mathrm{~L}$ cylindrical reactor. The reactor was operated at different $\mathrm{pH}$ values (5.23, 7, and 10). A current density power supply provided 1,2 , and $3 \mathrm{~A}$ and $5-6.75 \mathrm{~V}$, corresponding to a current density of $3.5,7$, and $10 \mathrm{~mA} \cdot \mathrm{cm}^{-2}$.

The experiment design used included the two factors of $\mathrm{pH}$ and current density. The levels of each of the factors are listed in Table 2. Different aliquots were taken, and the chemical oxygen demand (COD), biochemical oxygen demand $\left(\mathrm{BOD}_{5}\right)$, color, turbidity, and conductivity were analyzed. The boron-doped diamond electrodes (BDD) were cleaned for one hour in $\mathrm{Na}_{2} \mathrm{SO}_{4}(0.03 \mathrm{M})$ after each experiment to remove adsorbed molecules at the electrode surface, and then they were rinsed with distilled water.

2.3. Coupled System with Salix babylonica Treatment. For Salix babylonica treatment, secondary branches of weeping willows located in five regions near the discharge site were collected based on some defined phenotypic characteristics: intense green color, wide coverage, height greater than 8 meters, absence of pests, and straight shaft. Branch cuttings of $20 \mathrm{~cm}$ in length were placed in hydroponics [28] in $1 \mathrm{~L}$ containers with $300 \mathrm{~mL}$ of distilled water. They
TABLe 3: Physicochemical characterization of textile wastewater.

\begin{tabular}{|c|c|}
\hline Parameter & Raw wastewater \\
\hline $\mathrm{pH}$ & 5.23 \\
\hline Acidity $\left(\mathrm{mg} / \mathrm{L} \mathrm{CaCO}_{3}\right)$ & 962.8 \\
\hline Alkalinity $\left(\mathrm{mg} / \mathrm{L} \mathrm{CaCO}_{3}\right)$ & 1000 \\
\hline $\mathrm{BOD}(\mathrm{mg} / \mathrm{L})$ & 1400 \\
\hline $\mathrm{BOD} / \mathrm{COD}$ & 0.7 \\
\hline $\mathrm{COD}(\mathrm{mg} / \mathrm{L})$ & 2022 \\
\hline Color (Pt-Co U) & 3000 \\
\hline Chlorides $\left(\mathrm{mg} / \mathrm{L} \mathrm{Cl}^{-}\right)$ & 843.71 \\
\hline $\mathrm{EC}(\mathrm{mS} / \mathrm{cm})$ & 2.811 \\
\hline Hardness $\left(\mathrm{mg} / \mathrm{L} \mathrm{CaCO}_{3}\right)$ & 546.2 \\
\hline $\mathrm{N}-\mathrm{NO}_{2}(\mathrm{mg} / \mathrm{L})$ & 0.848 \\
\hline $\mathrm{N}-\mathrm{NO}_{3}(\mathrm{mg} / \mathrm{L})$ & 17.28 \\
\hline $\mathrm{N}-\mathrm{NH}_{3}(\mathrm{mg} / \mathrm{L})$ & 4.72 \\
\hline Phosphorus (mg/L P) & 715.1 \\
\hline Sulfates $\left(\mathrm{mg} / \mathrm{L} \mathrm{SO}_{4}{ }^{2-}\right)$ & 429.5 \\
\hline Turbidity (NTU) & 735 \\
\hline TOC $(\mathrm{mg} / \mathrm{L})$ & 1396.6 \\
\hline TDS (mg/L) & 1367 \\
\hline $\mathrm{Ca}^{2+}(\mathrm{mg} / \mathrm{L})$ & 36.537 \\
\hline $\mathrm{K}^{+}(\mathrm{mg} / \mathrm{L})$ & 64.43 \\
\hline $\mathrm{Mg}^{2+}(\mathrm{mg} / \mathrm{L})$ & 17.346 \\
\hline $\mathrm{Na}^{+}(\mathrm{mg} / \mathrm{L})$ & 392.79 \\
\hline
\end{tabular}

were kept at room temperature $\left(19-22^{\circ} \mathrm{C}\right)$ for a normal photoperiod ( $12 \mathrm{~h}$ light, $12 \mathrm{~h}$ dark). Ten willows per region were placed in jars of $1 \mathrm{~L}$ and were then placed in $500 \mathrm{~mL}$ of textile wastewater. They remained in contact with wastewater for 15 days, and water aliquots were taken at baseline and at intervals of eight days. Likewise, the development of plants during those time periods was assessed.

\section{Methods of Analysis}

3.1. Physicochemical Characterization. The characterization of textile wastewater was performed. During both electrochemical and phytoremediation treatment, $\mathrm{COD}, \mathrm{BOD}_{5}$, color, turbidity, $\mathrm{pH}$, and electrolytic conductivity analyses were performed as indicated in the standard methods procedures by the American Public Health Association [38]. In addition, infrared spectroscopy of the raw and treated water was performed.

3.2. Biological Parameters. Once roots and leaves were developed in hydroponics, they were weighed on an analytical balance (BEL Engineering), and the lengths of the plants and roots were measured using a vernier. The numbers of roots and leaves were counted, and the leaf areas and photosynthetic pigments were measured by using the method that Val et al. [39] and Moisés et al. [40] established. These measurements were performed at the beginning of biological treatment and every eight days. 


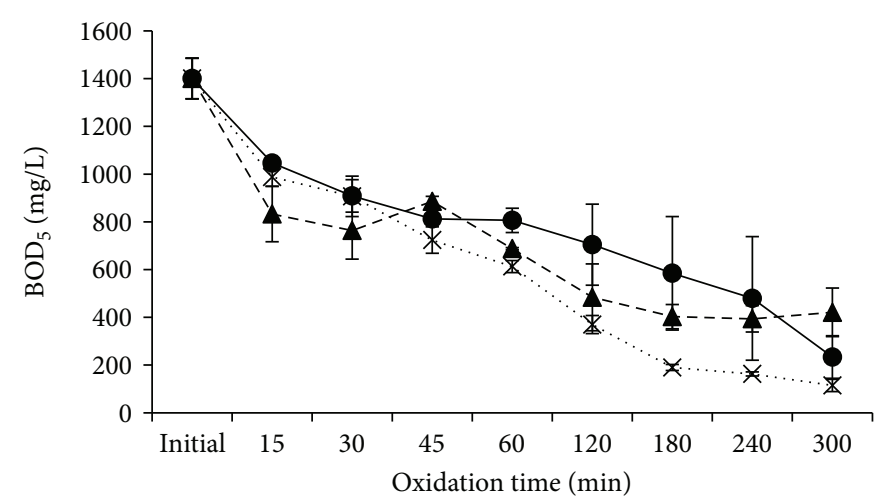

(a)

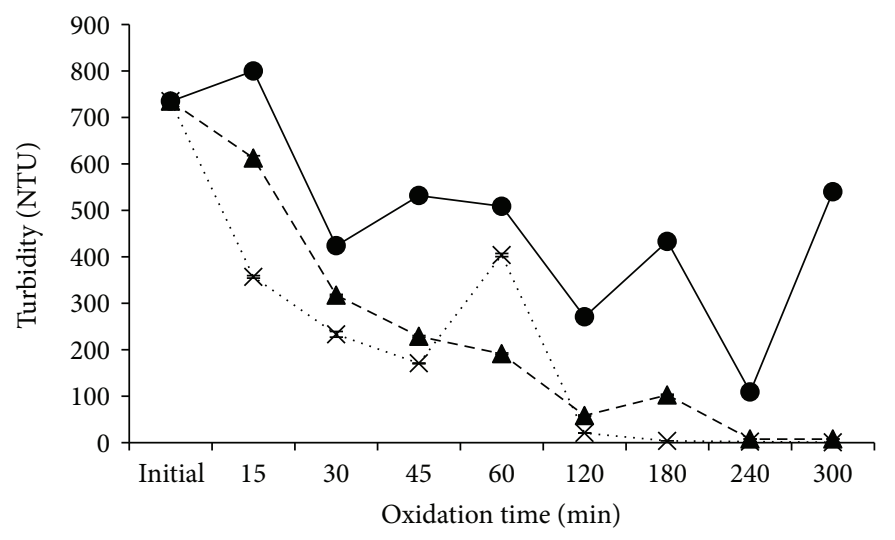

(c)

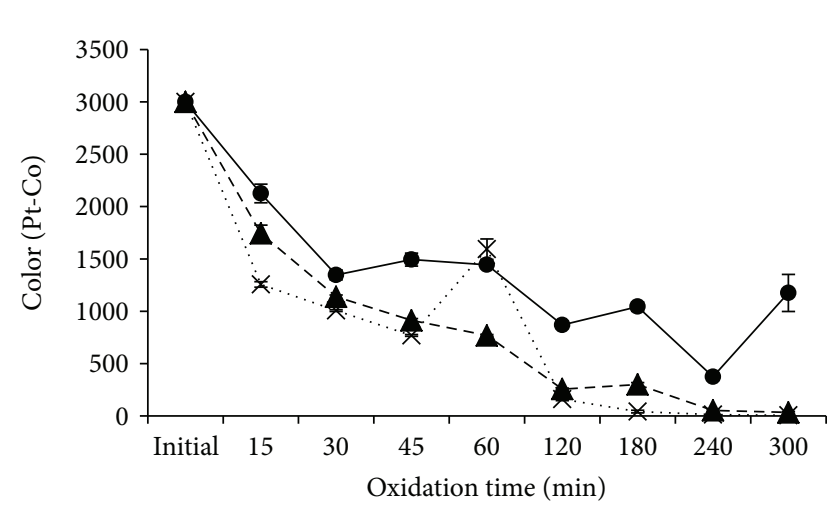

(b)

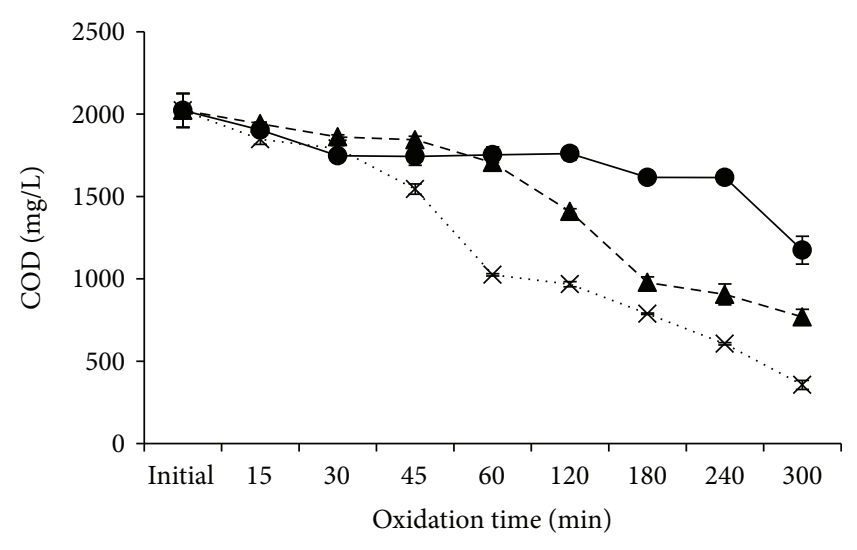

(d)

Figure 2: Behavior of (a) BOD 5 , (b) color, (c) turbidity, and (d) COD. Applying three current densities: $3.5 \mathrm{~mA} \cdot \mathrm{cm}^{-2}(\bullet), 7 \mathrm{~mA} \cdot \mathrm{cm}^{-2}(\boldsymbol{\Delta})$, and $10 \mathrm{~mA} \cdot \mathrm{cm}^{-2}(\mathrm{X})$, at $\mathrm{pH} 5.23$.

\section{Results and Discussion}

4.1. Wastewater Characterization. Physicochemical chacarcterization of textile wastewater is show in Table 3. The organic parameters indicate for the $\mathrm{BOD}_{5}$ a value of $1400 \mathrm{mg} / \mathrm{L}$. According to Mexican regulation, the allowed limit for discharging wastewater into rivers is $150 \mathrm{mg} / \mathrm{L}$. The COD was $2022 \mathrm{mg} / \mathrm{L}$; in this situation, the BOD/COD ratio (0.7) indicates good biodegradability [9]. The TOC was $1396.6 \mathrm{mg} / \mathrm{L}$, and the color was $3000 \mathrm{Pt}-\mathrm{Co} \mathrm{U}$; this high level of color stemmed from the indigo blue dye in the textile effluent. Regarding inorganic matter, different ions contribute to high conductivity $(2.811 \mathrm{mS} / \mathrm{cm})$. This parameter could be beneficial to the electrooxidation process because it was not necessary to add any support electrolyte. However, the presence of ions as nitrates, phosphates, and alkalinity could reduce the oxidation speed of organic compounds; on the other hand, chlorides $(843.71 \mathrm{mg} / \mathrm{L})$ could improve the indirect organic oxidation.

\subsection{Electrooxidation Treatment}

4.2.1. Current Density Effect. An important operating variable of the electrochemical process is the current density, which is the input current divided by the surface area of
TABle 4: Removal efficiencies of different parameters in the electrooxidation process.

\begin{tabular}{lcccccc}
\hline Experiment & $\mathrm{pH}$ & $\begin{array}{c}\text { Current } \\
\text { densities }\end{array}$ & $\begin{array}{c}\text { BOD } \\
(\%)\end{array}$ & $\begin{array}{c}\text { Color } \\
(\%)\end{array}$ & $\begin{array}{c}\text { Turbidity } \\
(\%)\end{array}$ & $\begin{array}{c}\text { COD } \\
(\%)\end{array}$ \\
\hline 1 & 5.23 & 3.5 & 83.33 & 60.83 & 26.53 & 41.95 \\
2 & 5.23 & 7 & 69.95 & 98.88 & 98.95 & 62.01 \\
3 & 5.23 & 10 & 91.81 & 99.81 & 99.91 & 82.39 \\
4 & 7 & 3.5 & 58.34 & 96.95 & 98.77 & 47.73 \\
5 & 7 & 7 & 91.15 & 99.66 & 99.77 & 63.14 \\
6 & 7 & 10 & 91.58 & 99.82 & 99.90 & 94.66 \\
7 & 10 & 3.5 & 58.56 & 92.45 & 98.09 & 82.10 \\
8 & 10 & 7 & 94.73 & 99.01 & 99.04 & 98.11 \\
9 & 10 & 10 & 94.38 & 97.04 & 93.87 & 95.03 \\
\hline
\end{tabular}

the electrode [11]. From other variables effective in the electrochemical process is current density as the rate of electrochemical reactions is controlled by this parameter. Further, the performance of electrodes is highly dependent on this parameter. Three different current densities were applied $\left(3.5,7\right.$, and $\left.10 \mathrm{~mA} \cdot \mathrm{cm}^{-2}\right)$ to investigate the effect in the oxidation process. All experiments were carried out at pH5.23 (sample pH), and in all cases, a direct effect of the current densities was observed: If the current increases, 


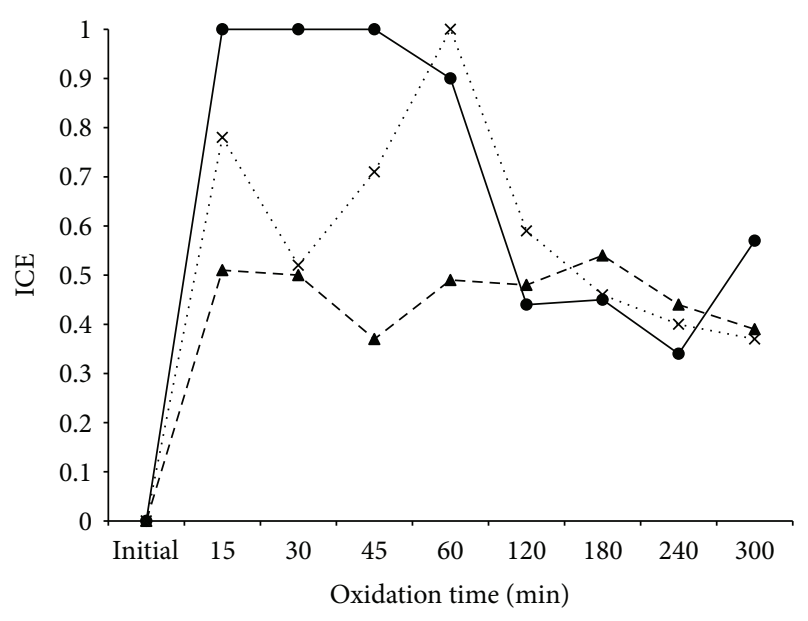

Figure 3: Instantaneous current efficiency (ICE) for the anodic oxidation process: $3.5 \mathrm{~mA} / \mathrm{cm}^{2}(\bullet), 7.0 \mathrm{~mA} / \mathrm{cm}^{2}(\boldsymbol{\Delta})$, and $10 \mathrm{~mA} /$ $\mathrm{cm}^{2}(\mathrm{X})$.

the removal efficiency increases. This could be due to the increased rate of the generation of oxidants, such as hydroxyl radicals and chlorine/hypochlorite at higher current densities [6]. The results at different densities are shown in Figure 2. The best removal efficiency was when $10 \mathrm{~mA} \cdot \mathrm{cm}^{-2}$ was applied. $\mathrm{BOD}_{5}$ was reduced considerably from $1400 \mathrm{mg} / \mathrm{L}$ to $114 \mathrm{mg} / \mathrm{L}$ with $92 \%$ of efficiency; COD was $2022 \mathrm{mg} / \mathrm{L}$ and was reduced to $356.05 \mathrm{mg} / \mathrm{L}$ with $82 \%$ of removal efficiency; color was reduced from 3000 Pt-Co U to 5.5 Pt-Co U (99.8\% removal efficiency); and initial turbidity was $735 \mathrm{NTU}$ and at the end of the process was $0.65 \mathrm{NTU}$, achieving $99.99 \%$ of removal efficiency. Efficiency was measured during $300 \mathrm{~min}$ of treatment time (Table 4).

The instantaneous current efficiency (ICE) for the anodic oxidation was calculated from the values of COD using

$$
\mathrm{ICE}=F V \frac{\mathrm{COD}_{i}-\mathrm{COD}_{t}}{8 I \Delta t}
$$

where $F$ is the Faraday constant $(96487 \mathrm{C} / \mathrm{mol}), V$ is the volume (L), $\mathrm{COD}_{i}$ and $\mathrm{COD}_{t}$ are the chemical oxygen demand $(\mathrm{g} / \mathrm{L})$ at initial time and time $t, I$ is the applied current $(\mathrm{A})$, $\Delta t$ is the treatment time (s), and 8 is the equivalent mass of oxygen $\left(\mathrm{g} \cdot \mathrm{eq}^{-1}\right)$. The instantaneous current efficiency (ICE) decreased during the electrolysis as wastewater was oxidized. This behavior is shown in Figure 3.

The best ICE percentage was when the lowest current was applied $1 \mathrm{~A}\left(3.5 \mathrm{~mA} \cdot \mathrm{cm}^{-2}\right)$ in the middle stage of electrooxidation $(15-45 \mathrm{~min})$. This may be attributed to the presence of a higher concentration of organics near the electrodes. This indicates that the electrooxidation was under the current control regime at least in the middle stage of electrooxidation. The ICE decreased after $60 \mathrm{~min}$ of the electrooxidation process. This may be due to the depletion of the concentration of organics on the electrode surface.

The energy consumption per volume of treated effluent was estimated and expressed in $\mathrm{kWh} \cdot \mathrm{m}^{-3}$. The average cell voltage during the electrolysis (cell voltage is reasonably constant with just some minor oscillations, and for this reason, the average cell voltage was calculated) was measured to calculate the energy consumption by using [15]

$$
\text { Energy consumption }=\frac{\Delta E_{\mathrm{c}} \times I \times t}{1000 \times V},
$$

where $t$ is the time of electrolysis $(\mathrm{h}) ; \Delta E_{\mathrm{c}}(\mathrm{V})$ and $I(\mathrm{~A})$ are the average cell voltage and the electrolysis current, respectively; and $V$ is the sample volume $\left(\mathrm{m}^{3}\right)$. According to the results, $5.87 \mathrm{kWh} \cdot \mathrm{m}^{-3}$ is required to oxidize the pollutants in the textile wastewater. In another study, a real textile effluent was treated using a BDD anode, applying a current density of $20 \mathrm{~mA} \cdot \mathrm{cm}^{-2}$. The energy consumption was $20 \mathrm{kWh} \cdot \mathrm{m}^{-3}[15]$.

The specific energy consumption $(\mathrm{Ec})$ in $\mathrm{kWh} \cdot(\mathrm{kg} \mathrm{COD})^{-1}$ removed was determined according to [37]

$$
\mathrm{Ec}=\frac{U I t / 60}{\left(\mathrm{COD}_{0}-\mathrm{COD}\right) V}
$$

where $U$ is the mean applied voltage $(\mathrm{V}), I$ is the current $(\mathrm{A}), t$ is the treatment time (min), $V$ is the liquid volume $(\mathrm{L})$, and $\mathrm{COD}_{0}$ and $\mathrm{COD}$ are the COD values $\left(\mathrm{g} \mathrm{O}_{2} \mathrm{~L}^{-1}\right)$ at times 0 and $t$. The results showed that $21.87 \mathrm{kWh} \cdot(\mathrm{kgCOD})^{-1}$ was required in the electrooxidation process. In a previous work, $95 \mathrm{kWh} \cdot(\mathrm{kgCOD})^{-1}$ was applied for the same COD removal [37].

4.2.2. pH Effect. The studies were performed at three different initial $\mathrm{pH}$ values $(5.23,7$, and 10$)$ to investigate their effects as depicted in Figure 4. The current density applied in these experiments was $3.5 \mathrm{~mA} \cdot \mathrm{cm}^{-2}$. At alkaline $\mathrm{pH}(10)$, the best efficiencies were achieved: COD (85.9\%), color (99.6\%), $\mathrm{BOD}_{5}(70.3 \%)$, and turbidity (99.7\%). However, an addition of $\mathrm{NaOH}$ was required to adjust the $\mathrm{pH}$, and this could be a disadvantage in the oxidation process.

The $\mathrm{pH}$ solution was an important factor for wastewater treatment. In anodic oxidation, many reports exist on the influence of $\mathrm{pH}$ solution, but the results are diverse and even contradictory due to different organic structures and electrode materials [1]. In an acidic solution, the degradation process of azo dyes is higher than in a basic solution, as in acidic solutions, chlorides are reduced to free chlorine, which is a dominant oxidizing agent [6]. During all experiments, the initial $\mathrm{pH}$ decreased during the treatment time (2.3-2.75). This could be attributed to the fragmentation of organic matter into carboxylic acids, carbonic acid, and ions as by-products of mineralization. Figure 5 shows the behavior of the conductivity during the treatment time; it increased at the end of the process probably as a result of the mineralization in the electrochemical oxidation process.

4.2.3. Degradation Mechanism. Previous research studies [41, 42] indicated that the oxidation of organics with concomitant oxygen evolution assumes that both organic oxidation and oxygen evolution take place on a BDD anode surface via the intermediation of hydroxyl radicals generated from the reaction with water shown in

$$
\mathrm{BDD}+\mathrm{H}_{2} \mathrm{O} \rightarrow \mathrm{BDD}(\mathrm{OH} \bullet)+\mathrm{H}^{+}+\mathrm{e}^{-}
$$




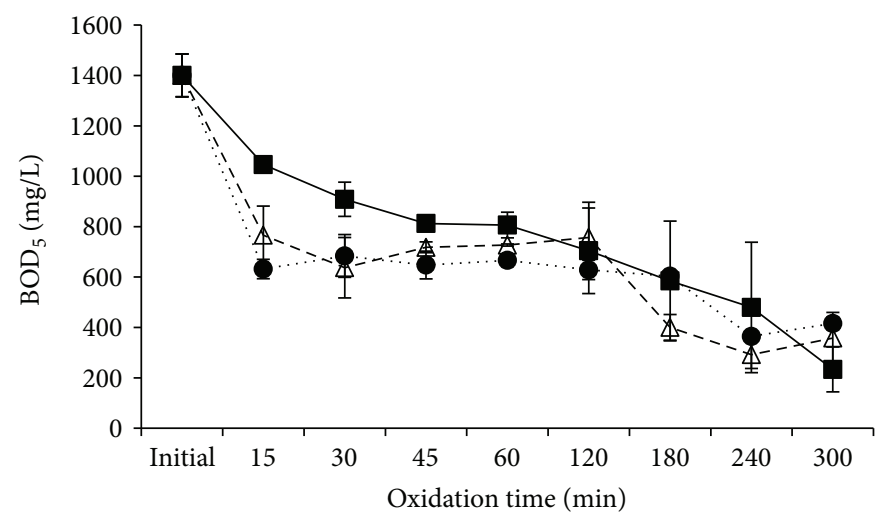

(a)

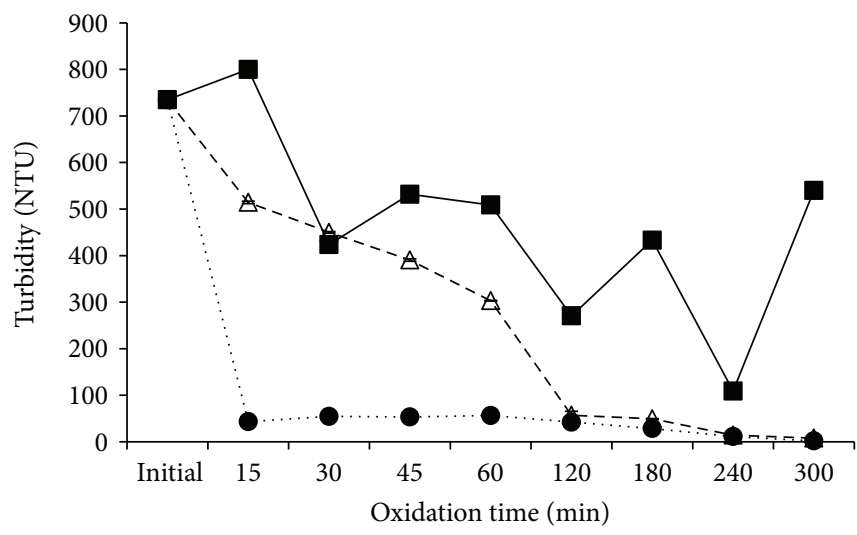

(c)

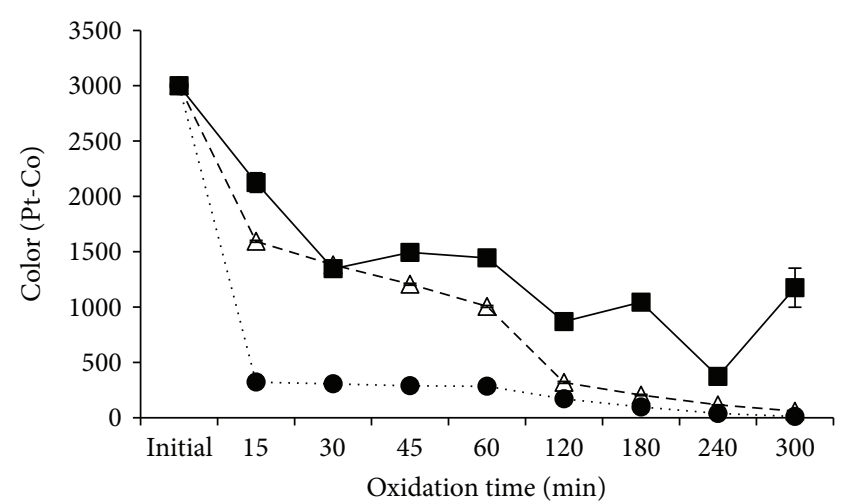

(b)

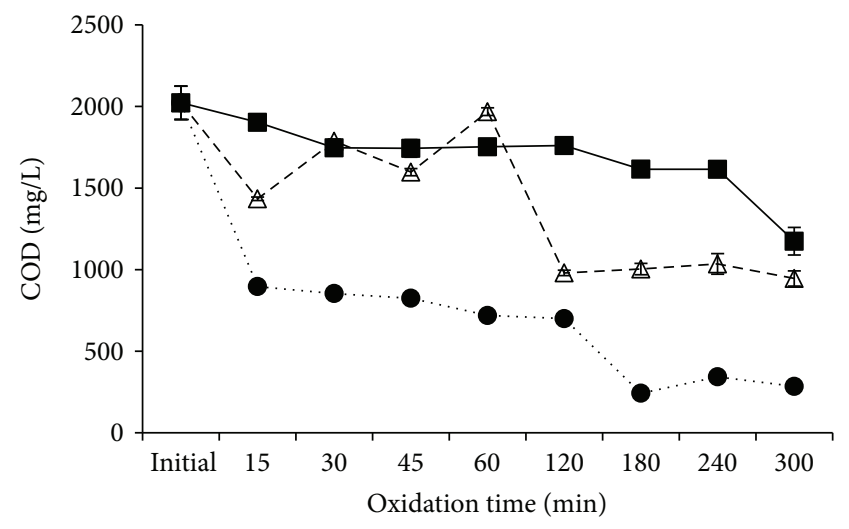

(d)

Figure 4: Behavior of (a) $\mathrm{BOD}_{5}$, (b) color, (c) turbidity, and (d) COD. Applying $3.5 \mathrm{~mA} \cdot \mathrm{cm}^{-2}$, at pH $5.23(\boldsymbol{\square}), 7(\Delta)$, and $10(\bullet)$.

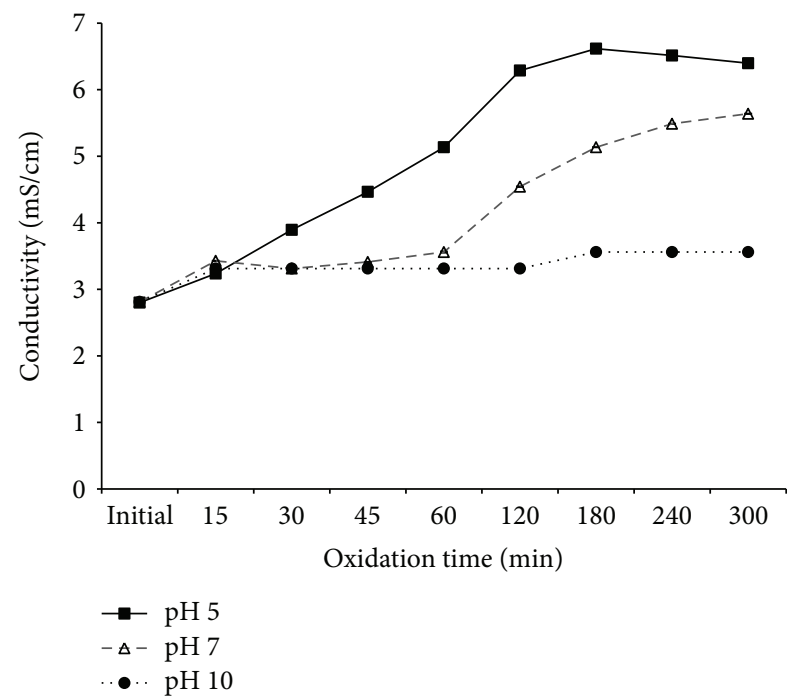

FIGURE 5: Conductivity behavior during the treatment time at three different $\mathrm{pH}$ values.

$$
\mathrm{BDD}(\mathrm{OH} \bullet)+\mathrm{R} \rightarrow \mathrm{BDD}+m \mathrm{CO}_{2}+n \mathrm{H}_{2} \mathrm{O}
$$

Reaction (4) is in competition with the side reaction of hydroxyl radical conversion to $\mathrm{O}_{2}$ without any participation of the anode surface as indicated in

$$
\mathrm{BDD}(\mathrm{OH} \bullet) \rightarrow \mathrm{BDD}+\frac{1}{2} \mathrm{O}_{2}+\mathrm{H}^{+}+\mathrm{e}^{-}
$$

Textile wastewater was analyzed via infrared spectroscopy before and after the electrochemical oxidation process, and the spectra are shown in Figure 6. The principal functional groups found in the aqueous solution of dye were $-\mathrm{NH}-$ $\left(3305 \mathrm{~cm}^{-1}\right)$, the $\mathrm{C}-\mathrm{H}$ aromatic bond $\left(2910\right.$ and $\left.2845 \mathrm{~cm}^{-1}\right)$, $-\mathrm{NH}_{3}{ }^{+}\left(2340 \mathrm{~cm}^{-1}\right)$, aromatic $-\mathrm{C}=\mathrm{C}-\left(1614 \mathrm{~cm}^{-1}\right)$, sulfoxides $\left(1101\right.$ and $\left.1022 \mathrm{~cm}^{-1}\right)$, and $\mathrm{C}-\mathrm{CO}-\mathrm{C}$ in ketones $\left(611 \mathrm{~cm}^{-1}\right)$. The spectra of oxidized water showed that the intensity of corresponding bands to sulfoxides and secondary amines diminished after treatment, whereas the bands of $\mathrm{R}-\mathrm{COOH}$ and $\mathrm{O}-\mathrm{C}=\mathrm{O}$ increased. In accordance with the above, the proposed dye degradation mechanism is shown in Figure 6.

\subsection{Phytoremediation with Salix babylonica}

4.3.1. Textile Wastewater. After oxidation treatment, the oxidized water was placed in contact with plants for 8 and 15 days, as shown in Figure 7. Parameters of the COD, color, and turbidity were minimally reduced. However, at 15 days of contact time, a visible reduction in color and turbidity was noted. According to the results, the plants assimilated better with the pollutants in the raw water than in the oxidized water due to the structural changes that the compounds suffered with the electrooxidation treatment. The coupled system (electrooxidation + phytoremediation) 


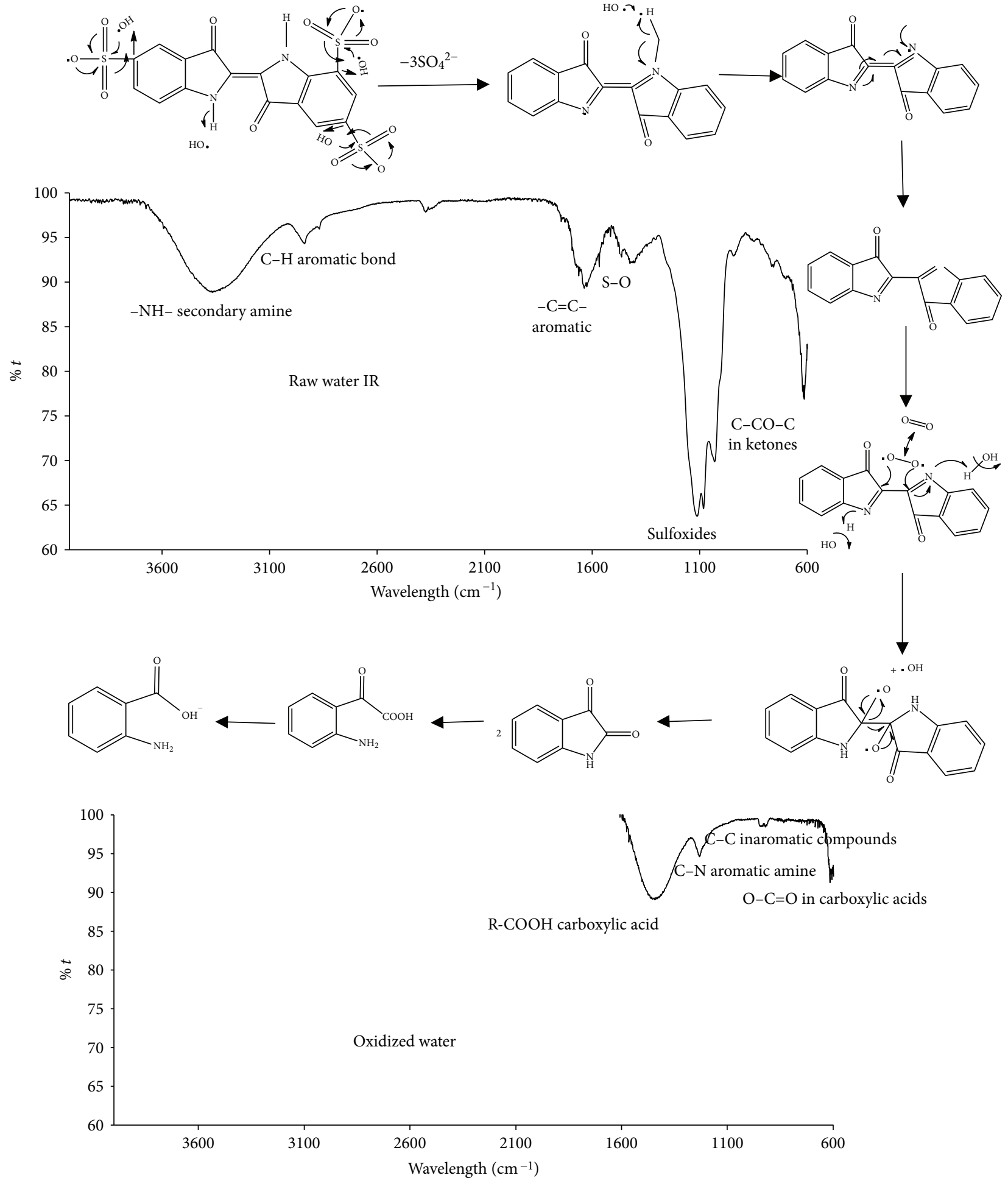

FIGURE 6: Diagram of the degradation mechanism proposed. Within the figure are shown the infrared spectra of raw water and oxidized water.

yielded a reduction of the COD by $14 \%$, color by $85 \%$, and turbidity by $93 \%$.

4.3.2. Salix babylonica Biomass. The willow biomass tolerance was analyzed by using Minitab 15.1.20 statistic program analysis of variance (ANOVA) to find significant differences between treatments. As shown in Figure 8(a), significant differences were found in the leaf numbers, leaf areas, and root numbers among the plants that were in contact with oxidized water for different amounts of time $(P<0.05 ; F=8.20)$. 


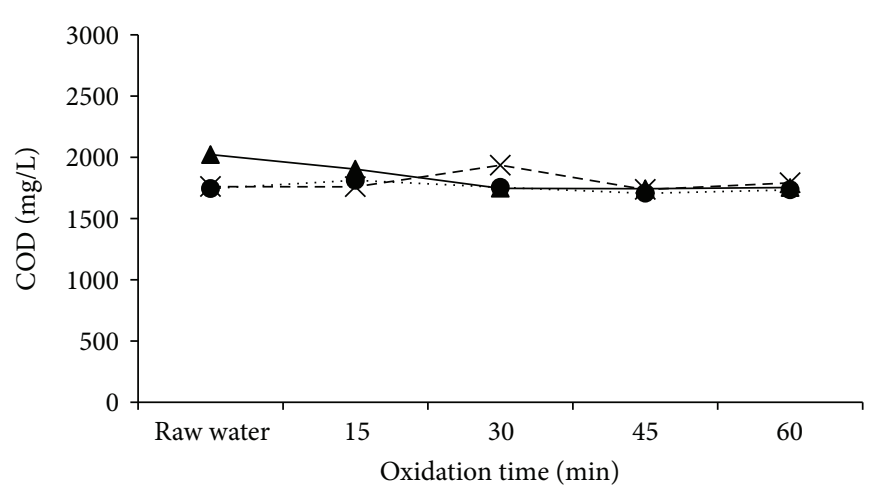

(a)

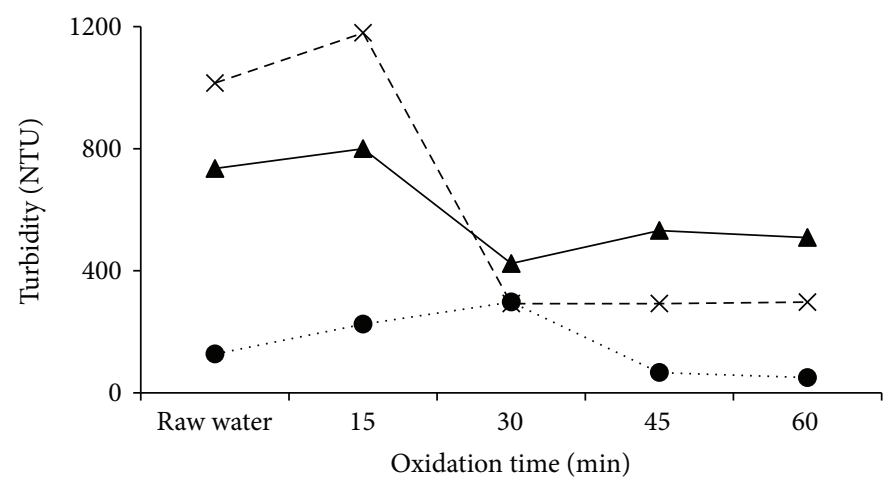

(c)

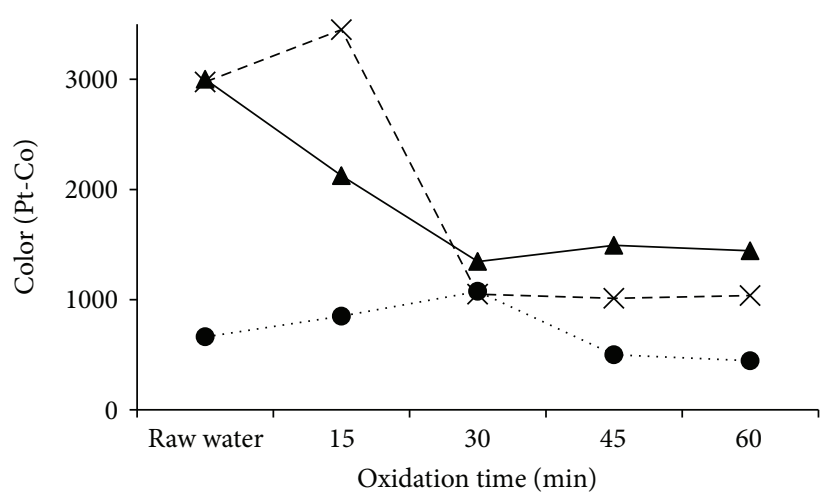

(b)

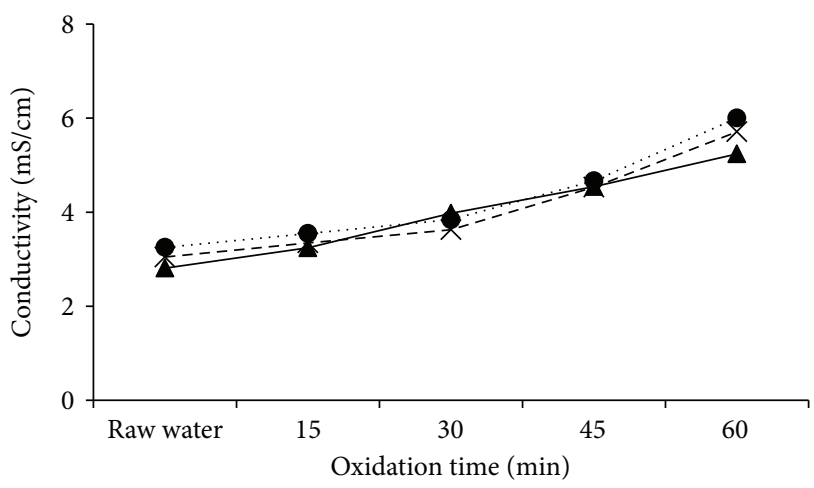

(d)

FIGURE 7: Behavior of (a) COD, (b) color, (c) turbidity, and (d) conductivity, with Salix babylonica contact at initial time ( $\mathbf{\Delta}), 8$ days $(\times)$, and 15 days $(\mathbf{O})$.

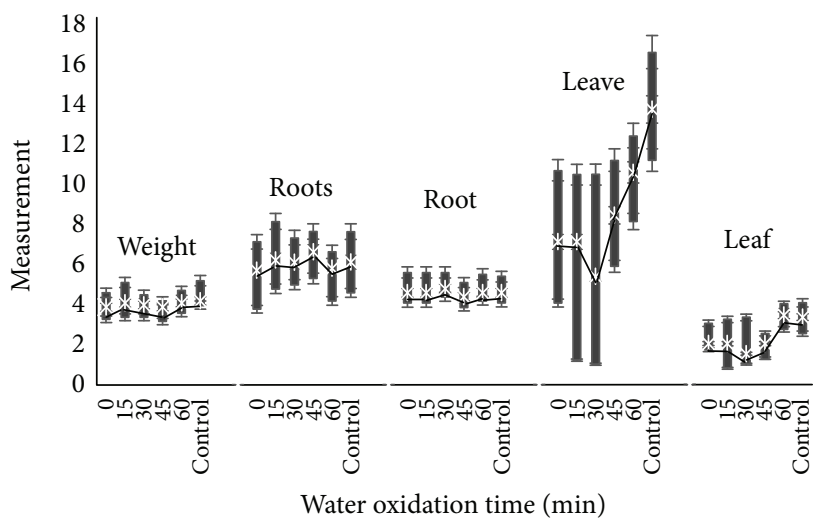

(a)

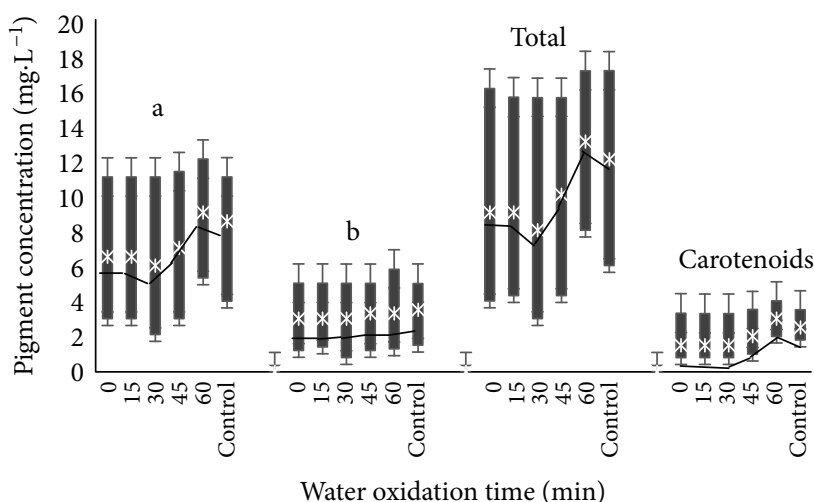

(b)

FiguRE 8: Willow tolerance (a) biomass parameters: weight $(\mathrm{g})$, root number, root length $(\mathrm{cm})$, leaf number, and leaf area $\left(\mathrm{cm}^{2}\right)$; $(\mathrm{b})$ pigment concentration $\left(\mathrm{mg} \cdot \mathrm{L}^{-1}\right)$ at different oxidized water contact times.

Willow plants in contact with oxidized water for 60 minutes reached a biomass close to that of the control plants. The same behavior was observed in the pigment concentration as shown in Figure 8(b). Willow plants tend to lose leaves in a stressful environment, but the root system and photosynthetic metabolism remain.

With respect to the contact time, willow plants reduced their photosynthetic metabolism and lost leaves at eight days of contact time, but after this time, such plants recovered their photosynthetic metabolism to some extent as shown in Figure 9. This could be because willow plants became adapted to the new environmental conditions. The mechanism by which Salix babylonica decreases color and pollutant concentration is unknown, but an increase in the concentration of chlorophylls indicates that the plant is photosynthesizing and thus absorbing nutrients from wastewater. 


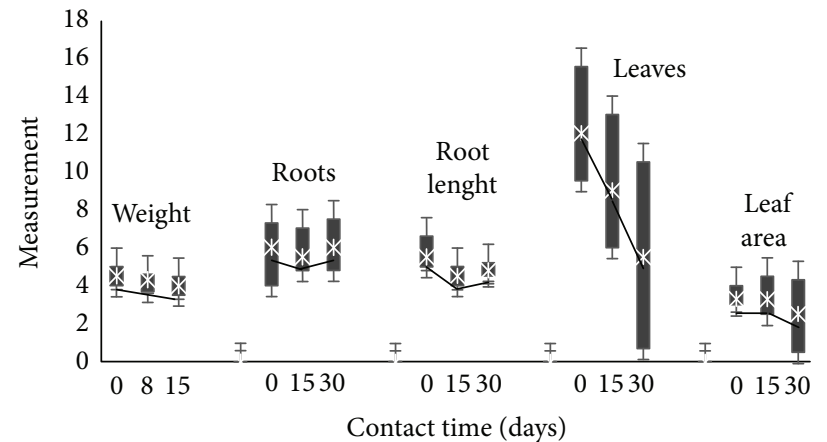

(a)

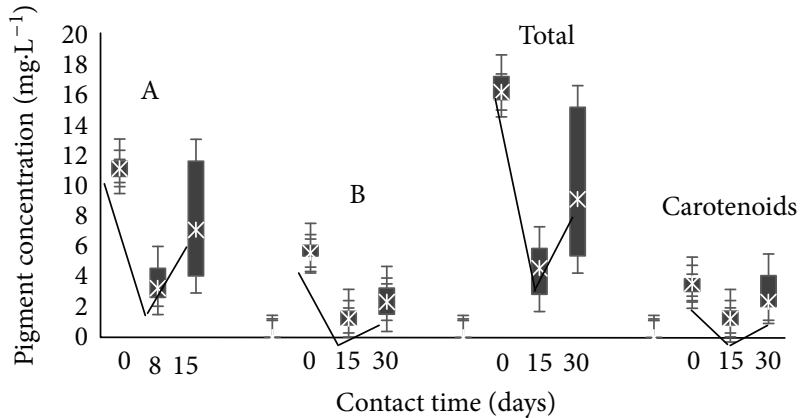

(b)

Figure 9: Willow tolerance (a) biomass parameters: weight (g), root number, root length ( $\mathrm{cm}$ ), leaf number, and leaf area ( $\left.\mathrm{cm}^{2}\right)$; (b) pigment concentration $\left(\mathrm{mg} \cdot \mathrm{L}^{-1}\right)$ at different contact times.

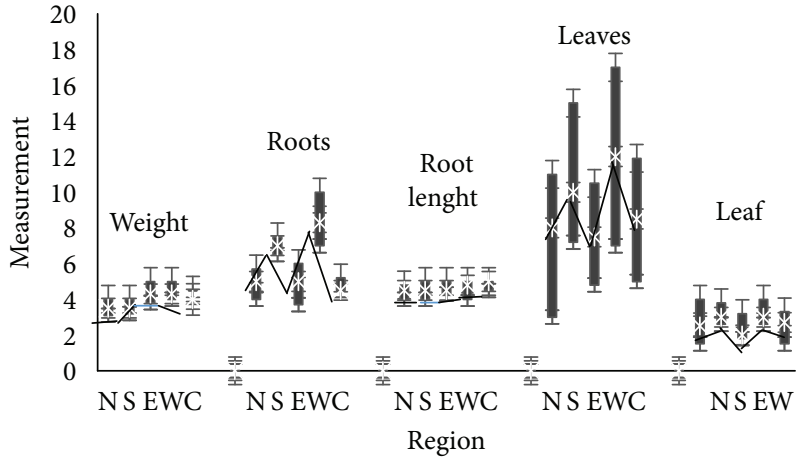

(a)

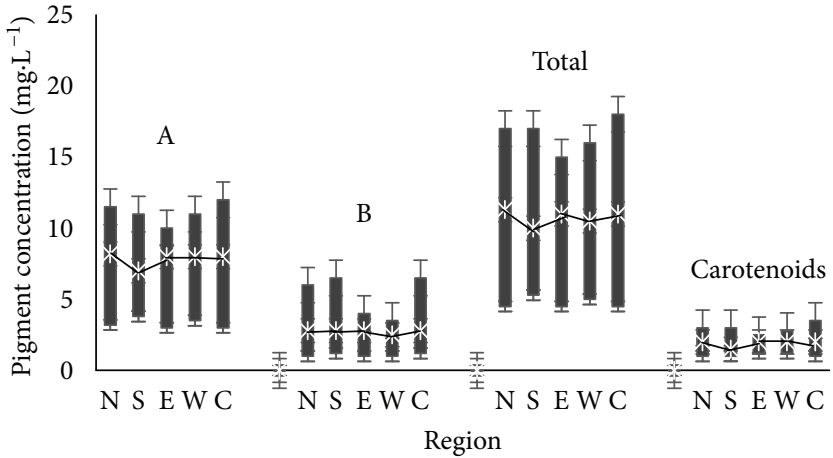

(b)

Figure 10: Willow tolerance (a) biomass parameters: weight $(\mathrm{g})$, root number, root length $(\mathrm{cm})$, leaf number, and leaf area $\left(\mathrm{cm}^{2}\right)$; $(\mathrm{b})$ pigment concentration $\left(\mathrm{mg}^{\mathrm{L}} \mathrm{L}^{-1}\right)$ from different regions: north $(\mathrm{N})$, south $(\mathrm{S})$, east $(\mathrm{E})$, west $(\mathrm{W})$, and center $(\mathrm{C})$.

Furthermore, the adsorption of contaminants in plant roots has been documented [20]. The results may indicate that the willow phenotype of the western region is characterized by very dense foliage and root system, by genetics, or by environmental influence, but in terms of photosynthetic metabolism, they are the same as the willows of the other regions (Figure 10).

\section{Conclusions}

Textile wastewater composition was favorable for carrying out electrochemical oxidation due to the high salt content. All experiments were carried out at the original $\mathrm{pH}$ (5.23), and it was determined that if the current density was increased, the removal efficiency increased. However, the current efficiency decreased during this process. For this reason, the lower current density was chosen $\left(3.5 \mathrm{~mA} / \mathrm{cm}^{-2}\right)$ as optimal. The infrared spectroscopy of the wastewater before and after electrooxidation showed a degradation of dye. The proposed degradation mechanism showed carboxylic acids and sulfates as degradation products. In the coupled system, a reduction of the COD was decreased by $14 \%$, color by $85 \%$, and turbidity by $93 \%$. The biomass and pigment of willow Salix babylonica demonstrated that this species has the ability to adapt to adverse conditions very quickly.

\section{Conflicts of Interest}

The authors declare that they have no conflicts of interest.

\section{Acknowledgments}

The authors thank Consejo Nacional de Ciencia y Tecnología Project 219743 and the scholarship 622274 for support during the development of this work.

\section{References}

[1] F. Guenfoud, M. Mokhtari, and H. Akrout, "Electrochemical degradation of malachite green with BDD electrodes: effect of electrochemical parameters," Diamond and Related Materials, vol. 46, pp. 8-14, 2014.

[2] T. Robinson, G. McMullan, R. Marchant, and P. Nigam, "Remediation of dyes in textile effluent: a critical review on current treatment technologies with a proposed alternative," Bioresource Technology, vol. 77, no. 3, pp. 247-255, 2001. 
[3] R. G. Saratale, G. D. Saratale, J. S. Chang, and S. P. Govindwar, "Bacterial decolorization and degradation of azo dyes: a review," Journal of the Taiwan Institute of Chemical Engineers, vol. 42, no. 1, pp. 138-157, 2011.

[4] I. Bazin, A. Ibn Hadj Hassine, Y. Haj Hamouda et al., "Estrogenic and anti-estrogenic activity of 23 commercial textile dyes," Ecotoxicology and Environmental Safety, vol. 85, pp. 131-136, 2012.

[5] V. Buscio, M. Crespi, and C. Gutiérrez-Bouzán, "Sustainable dyeing of denim using indigo dye recovered with polyvinylidene difluoride ultrafiltration membranes," Journal of Cleaner Production, vol. 91, pp. 201-207, 2015.

[6] P. Kariyajjanavar, N. Jogttappa, and Y. A. Nayaka, "Studies on degradation of reactive textile dyes solution by electrochemical method," Journal of Hazardous Materials, vol. 190, no. 1-3, pp. 952-961, 2011.

[7] A. Asghar, A. A. Abdul Raman, and W. M. A. Wan Daud, "Advanced oxidation processes for in-situ production of hydrogen peroxide/hydroxyl radical for textile wastewater treatment: a review," Journal of Cleaner Production, vol. 87, pp. 826-838, 2015.

[8] S. Hussain, S. Shaikh, and M. Farooqui, "COD reduction of waste water streams of active pharmaceutical ingredient atenolol manufacturing unit by advanced oxidation-Fenton process," Journal of Saudi Chemical Society, vol. 17, no. 2, pp. 199-202, 2013.

[9] J. L. De Morais and P. P. Zamora, "Use of advanced oxidation processes to improve the biodegradability of mature landfill leachates," Journal of Hazardous Materials, vol. 123, no. 1-3, pp. 181-186, 2005.

[10] A. R. Ribeiro, O. C. Nunes, M. F. R. Pereira, and A. M. T. Silva, "An overview on the advanced oxidation processes applied for the treatment of water pollutants defined in the recently launched Directive 2013/39/EU," Environment International, vol. 75, pp. 33-51, 2015.

[11] P. Asaithambi and M. Matheswaran, "Electrochemical treatment of simulated sugar industrial effluent: optimization and modeling using a response surface methodology," Arabian Journal of Chemistry, vol. 9, Supplement 2, pp. S981-S987, 2016.

[12] C. A. Martínez-Huitle and E. Brillas, "Decontamination of wastewaters containing synthetic organic dyes by electrochemical methods: a general review," Applied Catalysis B: Environmental, vol. 87, no. 3-4, pp. 105-145, 2009.

[13] S. A. Alves, T. C. R. Ferreira, N. S. Sabatini et al., "A comparative study of the electrochemical oxidation of the herbicide tebuthiuron using boron-doped diamond electrodes," Chemosphere, vol. 88, no. 2, pp. 155-160, 2012.

[14] E. Butrón, M. E. Juárez, M. Solis, M. Teutli, I. González, and J. L. Nava, "Electrochemical incineration of indigo textile dye in filter-press-type FM01-LC electrochemical cell using BDD electrodes," Electrochimica Acta, vol. 52, no. 24, pp. 68886894, 2007.

[15] C. A. Martínez-Huitle, E. V. Dos Santos, D. M. De Araújo, and M. Panizza, "Applicability of diamond electrode/anode to the electrochemical treatment of a real textile effluent," Journal of Electroanalytical Chemistry, vol. 674, pp. 103-107, 2012.

[16] C. A. Basha, K. V. Selvakumar, H. J. Prabhu, P. Sivashanmugam, and C. W. Lee, "Degradation studies for textile reactive dye by combined electrochemical, microbial and photocatalytic methods," Separation and Purification Technology, vol. 79, no. 3, pp. 303-309, 2011.
[17] A. V. Patil and J. P. Jadhav, "Evaluation of phytoremediation potential of Tagetes patula L. for the degradation of textile dye Reactive Blue 160 and assessment of the toxicity of degraded metabolites by cytogenotoxicity," Chemosphere, vol. 92, no. 2, pp. 225-232, 2013.

[18] N. R. Rane, V. V. Chandanshive, A. D. Watharkar et al., "Phytoremediation of sulfonated Remazol Red dye and textile effluents by Alternanthera philoxeroides: an anatomical, enzymatic and pilot scale study," Water Research, vol. 83, pp. 271$281,2015$.

[19] A. N. Kabra, R. V. Khandare, T. R. Waghmode, and S. P. Govindwar, "Phytoremediation of textile effluent and mixture of structurally different dyes by Glandularia pulchella (Sweet) Tronc," Chemosphere, vol. 87, no. 3, pp. 265-272, 2012.

[20] R. V. Khandare and S. P. Govindwar, "Phytoremediation of textile dyes and effluents: current scenario and future prospects," Biotechnology Advances, vol. 33, no. 8, pp. 1697-1714, 2015.

[21] L. C. Davies, C. C. Carias, J. M. Novais, and S. Martins-Dias, "Phytoremediation of textile effluents containing azo dye by using Phragmites australis in a vertical flow intermittent feeding constructed wetland," Ecological Engineering, vol. 25, no. 5, pp. 594-605, 2005.

[22] S. Torbati, A. R. Khataee, and A. Movafeghi, "Application of watercress (Nasturtium officinale R. Br.) for biotreatment of a textile dye: investigation of some physiological responses and effects of operational parameters," Chemical Engineering Research and Design, vol. 92, no. 10, pp. 1934-1941, 2014.

[23] F. Vafaei, A. Movafeghi, A. R. Khataee, M. Zarei, and S. Y. Salehi Lisar, "Potential of Hydrocotyle vulgaris for phytoremediation of a textile dye: inducing antioxidant response in roots and leaves," Ecotoxicology and Environmental Safety, vol. 93, pp. 128-134, 2013.

[24] A. D. Watharkar and J. P. Jadhav, "Detoxification and decolorization of a simulated textile dye mixture by phytoremediation using Petunia grandiflora and, Gailardia grandiflora: a plantplant consortial strategy," Ecotoxicology and Environmental Safety, vol. 103, pp. 1-8, 2014.

[25] M. N. Dos Santos Utmazian, G. Wieshammer, R. Vega, and W. W. Wenzel, "Hydroponic screening for metal resistance and accumulation of cadmium and zinc in twenty clones of willows and poplars," Environmental Pollution, vol. 148, no. 1, pp. 155-165, 2007.

[26] K. Drzewiecka, M. Mleczek, M. Gąsecka, Z. Magdziak, and P. Goliński, "Changes in Salix viminalis L. cv. 'Cannabina' morphology and physiology in response to nickel ions hydroponic investigations," Journal of Hazardous Materials, vol. 217-218, pp. 429-438, 2012.

[27] W. Yang, Z. Ding, F. Zhao et al., "Comparison of manganese tolerance and accumulation among 24 Salix clones in a hydroponic experiment: application for phytoremediation," Journal of Geochemical Exploration, vol. 149, pp. 1-7, 2015.

[28] C. Cosio, P. Vollenweider, and C. Keller, "Localization and effects of cadmium in leaves of a cadmium-tolerant willow (Salix viminalis L.): I. macrolocalization and phytotoxic effects of cadmium," Environmental and Experimental Botany, vol. 58, no. 1-3, pp. 64-74, 2006.

[29] A. Evlard, K. Sergeant, B. Printz et al., "A multiple-level study of metal tolerance in Salix fragilis and Salix aurita clones," Journal of Proteomics, vol. 101, pp. 113-129, 2014.

[30] M. Vaculík, C. Konlechner, I. Langer et al., "Root anatomy and element distribution vary between two Salix caprea isolates 
with different Cd accumulation capacities," Environmental Pollution, vol. 163, pp. 117-126, 2012.

[31] M. Mleczek, M. Łukaszewski, Z. Kaczmarek, I. Rissmann, and P. Golinski, "Efficiency of selected heavy metals accumulation by Salix viminalis roots," Environmental and Experimental Botany, vol. 65, no. 1, pp. 48-53, 2009.

[32] H. X. Corseuil and F. N. Moreno, "Phytoremediation potential of willow trees for aquifers contaminated with ethanolblended gasoline," Water Research, vol. 35, no. 12, pp. 3013$3017,2001$.

[33] S. V. Skaates, A. Ramaswami, and L. G. Anderson, "Transport and fate of dieldrin in poplar and willow trees analyzed by SPME," Chemosphere, vol. 61, no. 1, pp. 85-91, 2005.

[34] X.-Z. Yu, J. D. Gu, and S. Liu, "Biotransformation and metabolic response of cyanide in weeping willows," Journal of Hazardous Materials, vol. 147, no. 3, pp. 838-844, 2007.

[35] C. T. Cano-Rodríguez, G. Roa-Morales, A. Amaya-Chávez, R. A. Valdés-Arias, C. E. Barrera-Díaz, and P. BalderasHernández, "Tolerance of Myriophyllum aquaticum to exposure of industrial wastewater pretreatment with electrocoagulation and their efficiency in the removal of pollutants," Journal of Environmental Biology, vol. 35, no. 1, pp. 127-136, 2014.

[36] A. Eslami, M. Moradi, F. Ghanbari, and F. Mehdipour, "Decolorization and COD removal from real textile wastewater by chemical and electrochemical Fenton processes: a comparative study," Journal of Environmental Health Science and Engineering, vol. 11, no. 1, p. 31, 2013.

[37] E. Tsantaki, T. Velegraki, A. Katsaounis, and D. Mantzavinos, "Anodic oxidation of textile dyehouse effluents on borondoped diamond electrode," Journal of Hazardous Materials, vol. 207-208, pp. 91-96, 2012.

[38] APHA and AWWA, Standard Methods for Examination of Water and Wastewater, American Public Health Association y Water Pollution Control Federation, Washington, DC, USA, 21st edition, 2005.

[39] J. Val, L. Heras, and E. Monge, "New equations for the determination of photosynthetic pigments in acetone," Annals Aula Dei, vol. 17, no. 3, pp. 231-238, 1985.

[40] T.-P. Moisés, B.-H. Patricia, C. E. Barrera-Díaz, R.-M. Gabriela, and R. Natividad-Rangel, "Treatment of industrial effluents by a continuous system: electrocoagulation - activated sludge," Bioresource Technology, vol. 101, no. 20, pp. 7761-7766, 2010.

[41] A. Kapałka, G. Fóti, and C. Comninellis, "Investigations of electrochemical oxygen transfer reaction on boron-doped diamond electrodes," Electrochimica Acta, vol. 53, no. 4, pp. 1954-1961, 2007.

[42] I. Linares-Hernández, C. Barrera-Díaz, B. Bilyeu, P. JuárezGarcíaRojas, and E. Campos-Medina, "A combined electrocoagulation-electrooxidation treatment for industrial wastewater," Journal of Hazardous Materials, vol. 175, no. 1-3, pp. 688-694, 2010. 

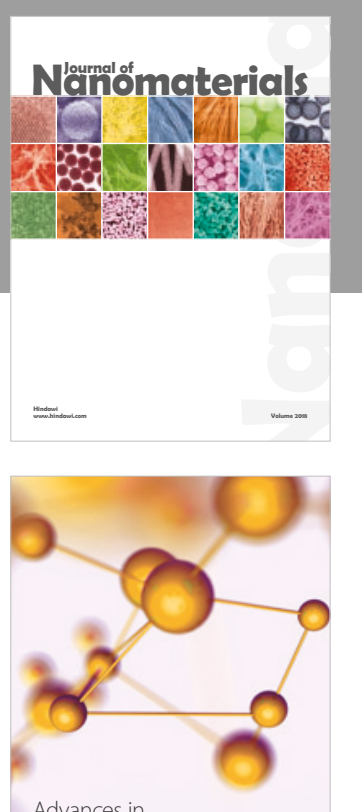

Physical Chemistry
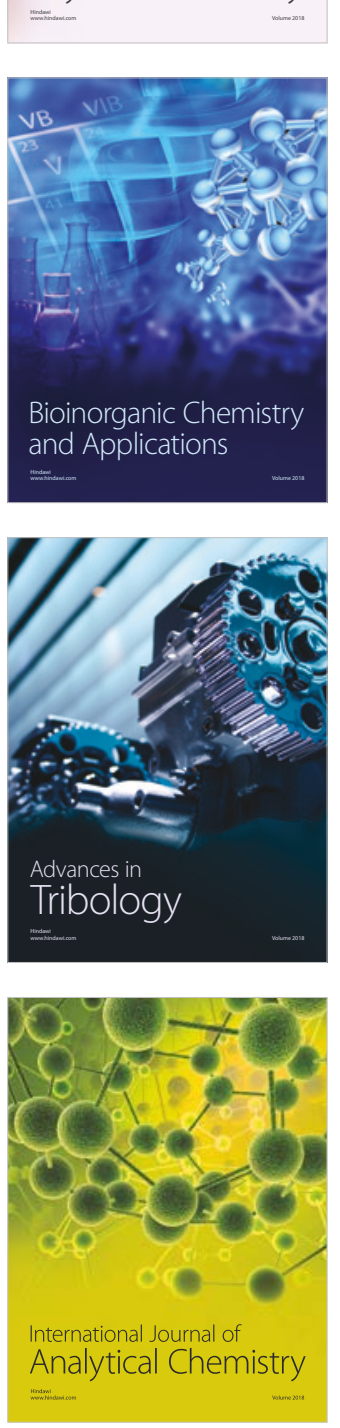

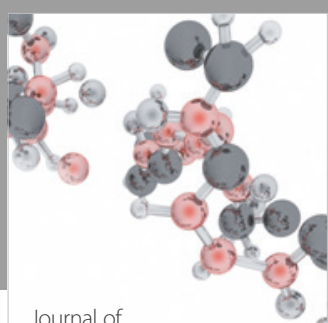

Analytical Methods

in Chemistry

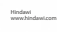

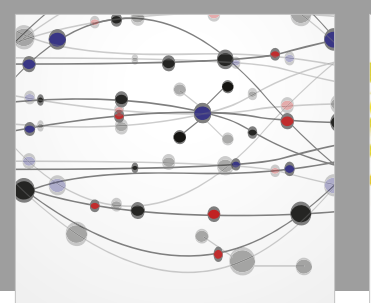

The Scientific World Journal

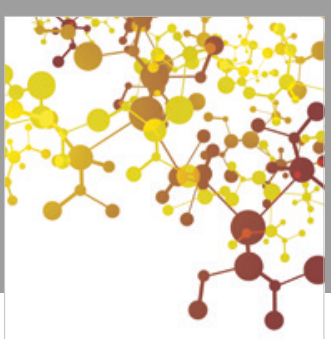

Journal of

Applied Chemistry
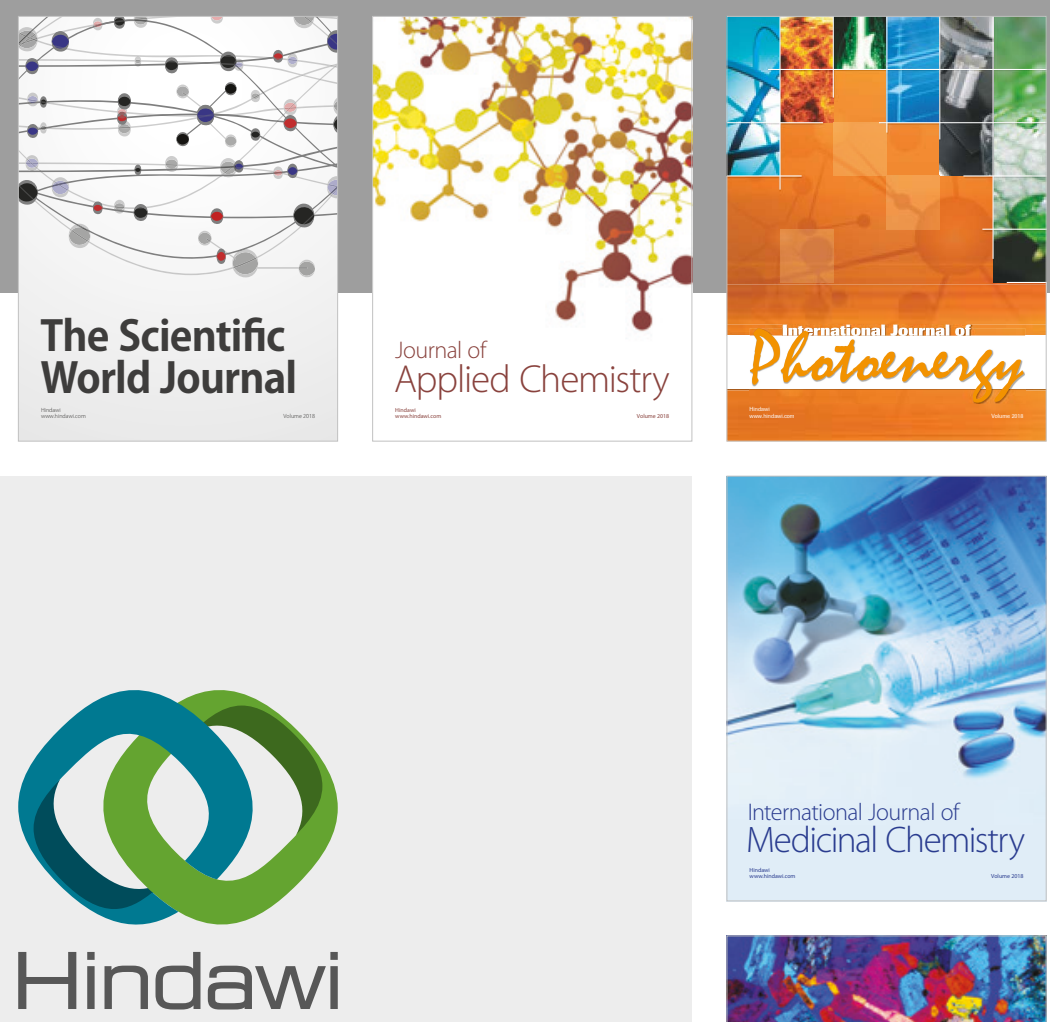

Submit your manuscripts at

www.hindawi.com
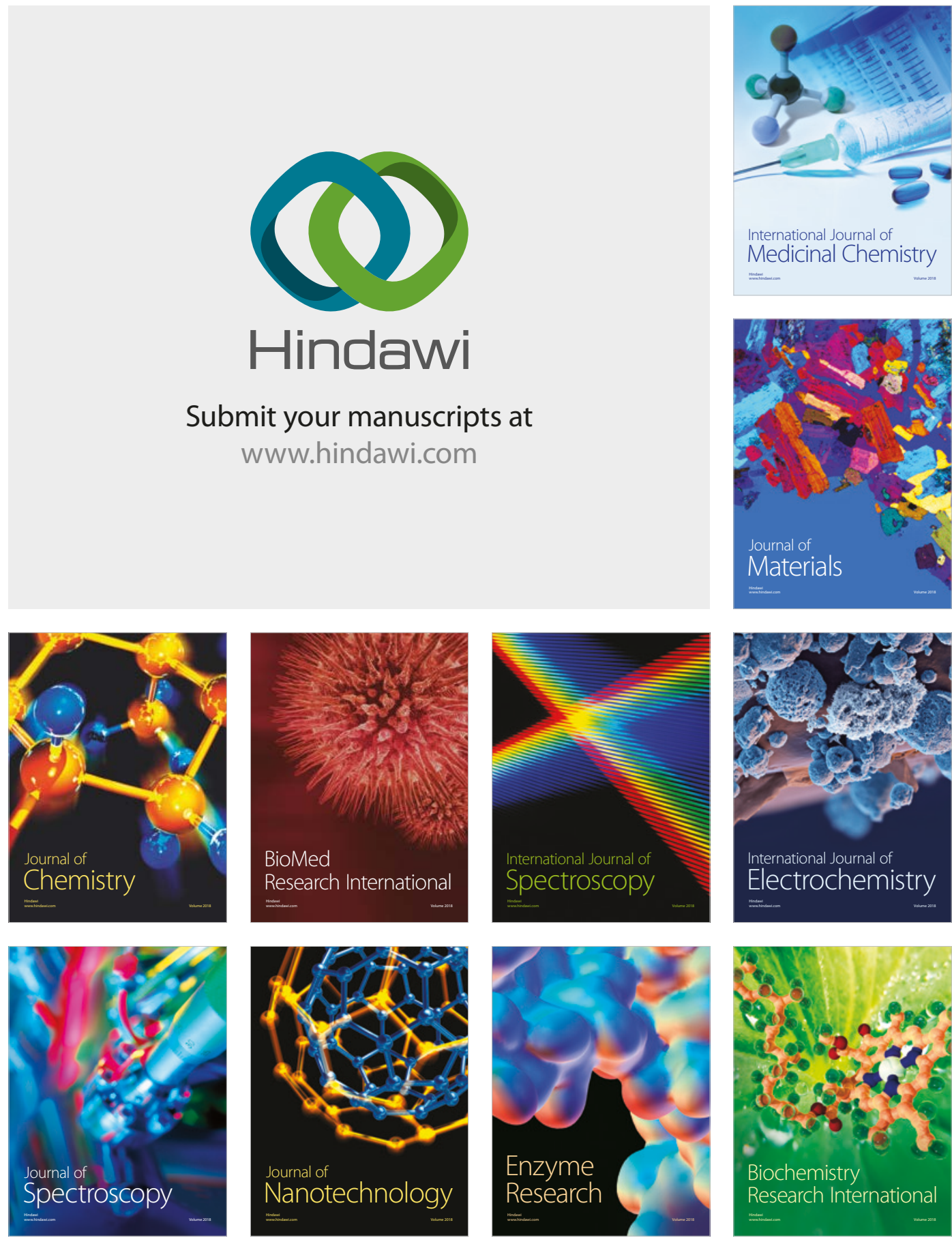
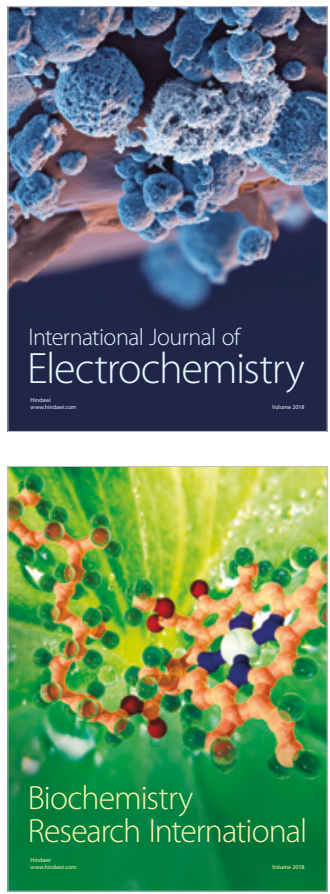